\title{
Het grievenstelsel (een evaluatie: nodig/wenselijk, alternatieven?)
}

\author{
Verslag van de najaarsvergadering 2014 van de Nederlandse Vereniging voor Procesrecht
}

\author{
Mr.P.E. Ernste $e^{*}$
}

Tijdens de najaarsvergadering van de Nederlandse Vereniging voor Procesrecht (hierna: NVvP) stond het grievenstelsel centraal. De vergadering, onder voorzitterschap van prof. mr. C.J.M. Klaassen, discussieerde over voornoemd onderwerp naar aanleiding van inleidingen van mr. G.C. Makkink, mr. dr. R.J. Koopman en prof. mr. A.I.M. van Mierlo.

De voorzitter licht het onderwerp toe. Het bestuur heeft dit onderwerp op de agenda gezet, omdat het grievenstelsel, en de daarmee samenhangende devolutieve werking, de afbakening van de rechtsstrijd in appel raakt en daarmee ook de toegang tot de appelrechtspraak. Dit laatste is een fundamenteel aspect van onze rechtspleging. Het conceptwetsvoorstel tot wijziging van het Wetboek van Burgerlijke Rechtsvordering in verband met vereenvoudiging en digitalisering van het procesrecht in hoger beroep en cassatie laat echter het grievenstelsel bewust buiten beschouwing. ${ }^{1}$ Uit de toelichting op dit conceptwetsvoorstel blijkt dat onder verwijzing naar de Agenda voor de appelrechtspraak 2020, zoals opgesteld door de hoven, het grievenstelsel buiten beschouwing blijft omdat de discussie hierover nog niet is uitgekristalliseerd. ${ }^{2}$ Dit verbaast de voorzitter, omdat de titel van het wetsvoorstel niet enkel strekt tot digitalisering van het appelprocesrecht, maar ook tot vereenvoudiging ervan. Wanneer gesproken wordt over vereenvoudiging van het appelrecht dient volgens haar ook te worden gekeken naar het grievenstelsel en de daarmee samenhangende devolutieve werking. Aangezet door de opmerking in de toelichting dat het grievenstelsel nadere discussie behoeft, heeft het bestuur van de NVvP besloten dit onderwerp op de agenda te zetten. Volgens de voorzitter is het grievenstelsel een ingewikkeld stelsel. Zij verwijst in dit verband naar een bijdrage van Wesseling-van Gent, die hierover het volgende heeft geschreven: 'Deze wordt als ingewikkeld ervaren en minst genomen komen per jaar enkele ongelukken voor.' Wesseling-

* Mr. P.E. Ernste is universitair docent burgerlijk (proces)recht aan de Radboud Universiteit Nijmegen. Dit is een bewerking van het verslag dat - samen met de tekst van de inleidingen - wordt opgenomen in een binnenkort te verschijnen uitgave van de Nederlandse Vereniging voor Procesrecht.

1. Het conceptwetsvoorstel is te raadplegen op <www.rijksoverheid.nl>.

2. Concept MvT wijziging Wetboek van Burgerlijke Rechtsvordering voor digitalisering procesrecht, p. 6. Te raadplegen op <www. rijksoverheid. $\mathrm{nl}>$. van Gent is overigens wel een voorstander van het grievenstelsel, omdat dit stelsel als belangrijk voordeel heeft dat het de geïntimeerde beschermt. ${ }^{3}$ De voorzitter refereert ook aan een bijdrage van Asser, waarin hij zich eveneens heeft uitgelaten over het grievenstelsel. Hij spreekt over de 'deconstructie van het grievenstelsel en de devolutieve werking'. Asser merkt het grievenstelsel aan als een door de Hoge Raad gebouwde kathedraal, die hij vergelijkt met de 'Sagrada Família'. Het grievenstelsel is volgens hem een schitterend, maar moeilijk te doorgronden bouwwerk, dat voortdurend in aanbouw is. Vervolgens omschrijft Asser de knelpunten van het grievenstelsel en de devolutieve werking en komt hij tot de conclusie dat we van dit 'wangedrocht' af moeten. ${ }^{4}$

Of het grievenstelsel dient te worden afgeschaft, is de vraag die tijdens de vergadering van de NVvP ter discussie stond. Dit onderwerp werd belicht vanuit de visie van de rechter door mr. G.C. Makkink, vanuit fiscaalrechtelijke optiek door mr. dr. R.J. Koopman en vanuit de visie van de advocaat door prof. mr. A.I.M. van Mierlo.

\section{Inleiding mr. G.C. Makkink}

Stellingen:

1. Het grievenstelsel is een mijnenveld.

2. Uit een oogpunt van rechtsbescherming is het niet voldoende nog eens aan te wijzen waar die mijnen liggen.

\section{Inleiding}

Makkink richt zich in zijn inleiding op de vraag of het grievenstelsel, zoals dat zich in de rechtspraak heeft ontwikkeld, voldoende hanteerbaar is. Onder het begrip grievenstelsel verstaat hij ook de 'in beginsel strakke twee-conclusie-regel' en de devolutieve werking van het appel. Makkink heeft gekozen voor de praktische hanteerbaarheid als maatstaf, omdat een procedure in hoger beroep volgens hem niet iets uitzonderlijks is en niet voorbehouden is of behoort te zijn aan een selecte groep van specialisten.

3. E.M. Wesseling-van Gent, Renovatie en innovatie van het civiele appel, TCR 2014, afl. 3, p. 66-70.

4. W.D.H. Asser, Deconstructie van grievenstelsel/devolutieve werking. Een appel aan Hoge Raad en de hoven, TCR 2014, afl. 4, p. 101-102. 
Zijn stelling dat het grievenstelsel een mijnenveld is, illustreert Makkink allereerst door een bespreking van enkele arresten van de Hoge Raad. Het eerste arrest dat hij bespreekt, is het arrest Fafianie/KSN. ${ }^{5}$ Volgens Makkink heeft in dit arrest de positieve zijde van de devolutieve werking forse schade opgelopen. De positieve zijde van de devolutieve werking houdt in dat een geïntimeerde, voor zover hij in het dictum van het vonnis in eerste aanleg in het gelijk is gesteld, zijn stellingen en gronden die in eerste aanleg buiten behandeling zijn gelaten of zijn verworpen in hoger beroep, niet bij wijze van incidenteel appel opnieuw aan de orde hoeft te stellen. In dit arrest speelde het volgende. Fafianie stelt een loonvordering in tegen werkgever KSN. KSN voert primair als verweer dat tussen partijen geen arbeidsovereenkomst heeft bestaan en subsidiair dat Fafianie slechts over een beperkte periode aanspraak heeft op loon, omdat hij slechts gedurende die beperkte periode beschikbaar was om de overeengekomen werkzaamheden te verrichten. De kantonrechter verwerpt het primaire verweer en honoreert het subsidiaire verweer en wijst de loonvordering toe over een beperkte periode. Fafianie gaat in hoger beroep. KSN stelt geen incidenteel hoger beroep in, maar handhaaft uitdrukkelijk haar primaire verweer dat er tussen partijen geen arbeidsovereenkomst heeft bestaan. Onder verwijzing naar de devolutieve werking van het appel laat het hof bij tussenarrest KSN toe tot het leveren van tegenbewijs tegen het bestaan van de arbeidsovereenkomst tussen partijen. In het eindarrest oordeelt het hof dat KSN is geslaagd in dit bewijs en bekrachtigt het vonnis van de kantonrechter. Fafianie gaat in cassatie. De Hoge Raad oordeelt dat met het oog op het voorkomen van tegenstrijdige onherroepelijke uitspraken niet kan worden aanvaard dat het primaire verweer van KSN op grond van de hoofdregel van de devolutieve werking opnieuw wordt beoordeeld zonder dat KSN incidenteel appel heeft ingesteld tegen het voor haar ongunstige, op de verwerping van haar verweer berustende gedeelte van het dictum. Hiermee wil de Hoge Raad voorkomen dat dit gedeelte van het dictum in kracht van gewijsde gaat en de daaraan ten grondslag liggende beslissing van de eerste rechter gezag van gewijsde verkrijgt. Volgens Makkink is deze uitspraak in de literatuur ${ }^{6}$ kritisch ontvangen.

Een tweede arrest dat Makkink uitgebreid bespreekt ter onderbouwing van zijn eerste stelling, is het arrest Van Gaalen/LTO. ${ }^{7}$ In deze zaak speelde het volgende. LTO eist in conventie van haar voormalige werknemer Van Gaalen een boete wegens schending van een concurrentiebeding en Van Gaalen eist in reconventie een verklaring voor recht dat tussen partijen geen concurrentiebeding geldt. De kantonrechter oordeelt dat Van Gaalen het concurrentiebeding meerdere malen heeft overtreden, maar matigt de boete die Van Gaalen is verschuldigd. De door Van Gaalen in reconventie gevorderde verklaring voor recht wijst de kantonrechter af. In het principaal

5. HR 30 maart 2012, NJ 2012/538 m.nt. Krans.

6. Makkink verwijst naar Asser/Bakkels, Hammerstein \& Wesseling-van Gent 4 2012/133; A. Hammerstein, Appelrechters kunnen van elkaar leren, TCR 2014, afl. 3, p. 71-75; A.C. van Schaick, Tegenstrijdige beslissingen, NTBR 2013/1.

7. HR 8 februari 2013, NJ 2014/175 m.nt. Snijders. appel voert Van Gaalen met name aan dat hij het concurrentiebeding niet heeft overtreden en vordert hij dat het hof de vordering van LTO alsnog afwijst. In het incidenteel appel voert Van Gaalen twee nieuwe gronden aan: (1) Van Gaalen zou niet in dienst zijn geweest bij LTO, maar bij een andere, gelieerde rechtspersoon; en (2) Van Gaalen is niet aan het concurrentiebeding gebonden omdat het niet opnieuw overeengekomen zou zijn toen zijn tijdelijke dienstverband werd omgezet in een arbeidsovereenkomst voor onbepaalde tijd. Het hof gaat expliciet voorbij aan deze gronden en verwijst naar de in beginsel strakke twee-conclusie-regel'. Van Gaalen gaat hiertegen in cassatie. De Hoge Raad overweegt vervolgens dat het Van Gaalen vrijstond om bij memorie van antwoord in incidenteel appel nieuwe verweren aan te voeren die strekten tot verwerping van het incidenteel appel van LTO.

Makkink is het eens met Snijders, die in zijn noot onder dit arrest schrijft dat dit arrest een loepzuivere toepassing behelst van enkele regels van ongeschreven appelprocesrecht, te weten: (1) een partij mag grieven in beginsel slechts aanvoeren in haar eerste processtuk in appel; (2) dat geldt ook voor nieuwe verweren die geen grieven zijn; en (3) bij toepassing van deze regels moet voor ogen worden gehouden dat het principale beroep en het incidentele beroep ten opzichte van elkaar een zelfstandige positie innemen. Hij is teleurgesteld over het feit dat de Hoge Raad geen uitdrukkelijke aandacht besteedt aan de verhouding tussen het arrest Van Gaalen/ LTO en Fafianie/KSN. De loepzuivere toepassing van het arrest Van Gaalen/LTO heeft volgens Makkink tot gevolg dat de deur wordt opengezet naar een innerlijk tegenstrijdige beslissing na cassatie en verwijzing. In het arrest Fafianie/KSN kende de Hoge Raad daarentegen veel gewicht toe aan het voorkomen van tegenstrijdige uitspraken. Verder vraagt hij zich af hoe het zit met het gezag van gewijsde van een dergelijke innerlijk tegenstrijdige uitspraak.

Makkink komt, op basis van de hierboven besproken arresten, tot de conclusie dat het grievenstelsel te complex is geworden. Hierdoor maken advocaten en rechters volgens hem te veel fouten, met als gevolg dat het materiële recht te vaak niet wordt verwezenlijkt.

Een andere reden waarom het huidige stelsel volgens Makkink niet houdbaar is, is gelegen in de doorwerking van het Europees consumentenrecht. Hij refereert in dit verband aan het arrest Heesakkers/Voets. ${ }^{8}$ In dit arrest vordert aannemer Voets van opdrachtgever Heesakkers betaling van de eindafrekening, vermeerderd met de contractuele rente van 2 procent per maand. In eerste aanleg wordt de vordering afgewezen. In hoger beroep wijst het hof de vordering grotendeels toe, vermeerderd met de contractuele rente, waartegen geen verweer was gevoerd. In cassatie legt Heesakkers aan de Hoge Raad de vraag voor of het hof op grond van Richtlijn 93/13/EEG betreffende oneerlijke bedingen in consumentenovereenkom$\operatorname{sten}^{9}$ ook buiten de grenzen van de rechtsstrijd had moeten

8. HR 13 september 2013, NJ 2014/274 m.nt. Krans.

9. Richtlijn 93/13/EEG van de Raad van 5 april 1993 (PbEG 1993, L 95/29). 
onderzoeken of het rentebeding, gezien de rente van 24 procent op jaarbasis, Heesakkers bond. De Hoge Raad beslist dat de appelrechter is gehouden ambtshalve na te gaan of een beding uit oogpunt van de in Richtlijn 93/13/EEG gegeven criteria oneerlijk is, ook indien hij daarbij buiten het door de grieven omsloten gebied moet treden, zij het dat hij niet tot onderzoek gehouden is als tegen de toe- of afwijzing van de desbetreffende vordering in hoger beroep niet is opgekomen en hij derhalve als appelrechter niet bevoegd is om over die vordering een beslissing te geven. Op basis van dit arrest komt Makkink tot de conclusie dat het grievenstelsel niet geldt in geval van oneerlijke bedingen in consumentenovereenkomsten. Het zou hem niet verbazen als andere onderdelen van het Europees privaatrecht in de toekomst ook eenzelfde openbareordestatus krijgen. Hij vraagt zich af of het grievenstelsel dan in zijn huidige vorm in redelijkheid te handhaven is.

Makkink noemt drie ingrediënten die volgens hem moeten leiden tot een verbetering van het appelrecht: (1) de goede procesorde, (2) betere communicatie en (3) rechtsbescherming als kerntaak.

Het moment voor communicatie is volgens hem de mondelinge behandeling na een schriftelijke ronde in hoger beroep. De ideale appelprocedure lijkt volgens hem op een verzoekschriftprocedure. Deze ideale procedure ziet er volgens hem als volgt uit. In het inleidend appelprocesstuk zet appellant de bezwaren tegen het vonnis uiteen en brengt desgewenst nieuwe feiten en argumenten naar voren. Hierop reageert de wederpartij bij memorie van antwoord of verweerschrift, waarin zij ook zelf bezwaren tegen het vonnis alsook nieuwe feiten of argumenten kan aanvoeren. Vervolgens vindt er dan een meervoudige mondelinge behandeling plaats, waarbij de rechter de leiding heeft. Een vast agendapunt van de mondelinge behandeling moet volgens Makkink de reikwijdte van het hoger beroep zijn. De appelrechter dient volgens hem op de zitting te toetsen of zijn analyse van de reikwijdte van het hoger beroep overeenstemt met de bedoeling van partijen. Indien dit niet het geval is, dienen partijen ter zitting de mogelijkheid te krijgen om alsnog nieuwe grieven of gronden aan te voeren. De goede procesorde moet als grens in acht worden genomen.

Makkink sluit zijn inleiding af met de conclusie dat hij een voorstander is van een meer pragmatische benadering van het grievenstelsel, waarbij het doel van het procesrecht, het bieden van rechtsbescherming, voor ogen wordt gehouden en het middel, open communicatie met partijen ter zitting, niet wordt geschuwd. Dit vergt volgens hem een onbevangen en nieuwsgierige houding van appelrechters.

\section{Discussie}

De voorzitter dankt Makkink voor zijn heldere inleiding en geeft aan dat ze zijn voorstel om standaard een mondelinge behandeling te houden, die een soort van regiezitting zou moeten zijn, interessant vindt. $\mathrm{Zij}$ vindt dit voorstel interessant omdat het conceptwetsvoorstel tot aanpassing van het hoger beroep hier nu juist niet in voorziet en de beslissing over het al dan niet houden van een mondelinge behandeling primair bij de rechter legt. $\mathrm{Z}_{\mathrm{ij}}$ is erg benieuwd hoe de rechters in de zaal tegen het voorstel van Makkink aan kijken dat standaard een mondelinge behandeling wordt geagendeerd om daarmee de rechtsstrijd in appel af te bakenen, om zo problemen rondom het grievenstelsel en de belemmeringen die dat oplevert ter verwezenlijking van het materiële recht, te ondervangen.

Valk (raadsheer bij het Hof Arnhem-Leeuwarden) wil graag de spanning onderstrepen die in het systeem is ontstaan door de wijze waarop het Europees consumentenrecht moet worden getoetst. Volgens hem bestaat die spanning niet alleen tussen aan de ene kant een norm van oneerlijke bedingen en aan de andere kant een norm van werkgeversaansprakelijkheid, maar bestaat die spanning ook tussen de verschillende procespartijen. Ter verduidelijking geeft hij een voorbeeld waarbij zowel een hoogleraar bestuursrecht als een zzp'er, die minder verdient dan de hoogleraar, betreffende eenzelfde gekocht apparaat procederen en beiden worden geconfronteerd met algemene voorwaarden. Door de lijnen die de Hoge Raad in de jurisprudentie heeft uitgezet, is het niet uit te leggen dat deze personen verschillend worden behandeld. De hoogleraar zal op basis hiervan immers een zeer actieve rechter treffen die zegt dat Europees consumentenrecht aan de orde is, terwijl de zzp'er, die veel minder in staat zal zijn om voor zichzelf op te komen, de klassieke lijdelijke rechter aantreft. Om deze spanning op te lossen moet volgens Valk principieel worden erkend dat niet alleen de rechter aan partijen kan voorhouden wat de rechtsstrijd is op basis van hetgeen partijen naar voren hebben gebracht, maar dat hij ook zelf zaken kan toevoegen aan de rechtsstrijd. Hierbij moet volgens Valk uiteraard wel het beginsel van hoor en wederhoor worden toegepast en de rechter mag geen feitelijke gronden aanvullen.

Makkink is het eens met Valk. Op dit punt bestaat volgens hem echter wel een verschil in perspectief tussen advocaten en rechters. In de tijd dat hij advocaat was, dacht hij hier ook anders over dan hij nu doet. Hij is een voorstander van het nemen van afscheid van de lijdelijkheid van de rechter. De rechter moet er echter wel voor waken dat het evenwicht tussen partijen niet wordt verstoord.

Kranenburg (advocaat te Amsterdam) geeft aan dat hij als advocaat bij het Gemeenschappelijk Hof van Justitie van de Nederlandse Antillen en Aruba een aantal jaren heeft geprocedeerd zonder grievenstelsel. Zijn ervaringen hiermee zijn positief. Volgens hem wordt er door advocaten minder krampachtig geprocedeerd. Hij heeft het idee dat veel grieven volstrekt nodeloos zijn en door raadsheren ook meteen opzij worden geschoven. Daarnaast heeft hij het gevoel dat het grievenstelsel rechtsongelijkheid in de hand werkt, doordat de ene raadsheer meer geneigd is zich strikt aan de grieven te houden dan de andere raadsheer. Op de Antillen kwam het wel meer voor dat een uitspraak verraste. Hiervoor is volgens hem de door Makkink voorgestelde comparitie van partijen een mooie 
oplossing. Hij maakt wel de kanttekening dat niet in alle zaken een comparitie van partijen noodzakelijk is. Indien in een later stadium een element nog niet aan de orde is geweest, kunnen partijen op verzoek van de rechter zich volgens hem hier ook bij akte over uitlaten.

Makkink reageert eerst op het punt betreffende de mondelinge behandeling en geeft aan dat hij voorstander is van een mondelinge behandeling in elke zaak. Hij vindt het vreemd dat hij als appelrechter over een zaak dient te beslissen, terwijl hij partijen niet heeft gezien. Dit is volgens hem alleen goed denkbaar als er een zuivere rechtsvraag aan de orde is, en dit is volgens hem zelden het geval.

Wiersma (gastdocent aan de Universiteit van Amsterdam) heeft een opmerking over de complexiteit van het grievenstelsel en de devolutieve werking. Volgens hem bevat het arrest Fafianie/KSN heel eenvoudige en heldere 'hard and fast rules': (1) wanneer een geïntimeerde niet incidenteel appelleert, krijgt geïntimeerde geen gunstiger dictum; en (2) reformatio in peius: als er niet wordt geappelleerd en de grieven stranden, blijft het vonnis intact. Dit zijn naar zijn idee heldere uitgangspunten, die gecodificeerd zouden moeten worden. Volgens hem is wonderlijk aan het arrest Fafianie/KSN dat de Hoge Raad, ondanks dat er niet incidenteel werd geappelleerd, oordeelde dat KSN toch uit was op een ander dictum. Dit vindt hij een rare stijlbreuk, waardoor het appelprocesrecht ingewikkelder is geworden. Dit ligt volgens hem echter niet aan de complexiteit van het stelsel zelf.

Makkink antwoordt dat voor mensen die zich in het appelprocesrecht specialiseren, het stelsel in ieder geval te begrijpen is. Volgens hem is het grievenstelsel en de daarmee samenhangende devolutieve werking echter wel ingewikkeld voor een advocaat die een of twee keer per jaar procedeert en die niet de hele dag bezig is met deze materie. Hij vindt het dan ook illustratief dat de arresten Fafianie/KSN en Van Galen/LTO echte huis-tuin-en-keukenzaken zijn. In beide arresten ging het om heel gewone arbeidszaken. Het waren geen zaken die over een heel complexe materie gingen en die alleen door gespecialiseerde advocaten konden worden gedaan.

Van Schaick (advocaat te Tilburg en hoogleraar aan de Universiteit van Tilburg) is het oneens met Valk en Makkink als het gaat om de vraag of de rechter in het debat de vrijheid zou moeten hebben om argumenten op te werpen die door partijen zelf niet zijn aangevoerd. Hij is een groot voorstander van de comparitie na antwoord, ook in hoger beroep. Hij is hier een voorstander van omdat het in een procedure vaak aankomt op het invullen van open normen, en dat gebeurt door de rechter, die daarbij vaak een persoonlijk element invoegt. Het is dan volgens hem goed dat partijen de gelegenheid krijgen om met de rechter daarover van gedachten te wisselen. Op een dergelijke comparitie zou de rechter niet ook argumenten moeten aandragen, omdat een rechter zichzelf dan in staat gaat vinden om te bedenken wat de meest wenselijke oplossing van het geschil tussen partijen is. Volgens Van Schaick moet er nu juist worden gestreefd naar een situatie waarbij partijen zelf zo veel mogelijk worden gestimuleerd om hun verantwoordelijkheid te nemen, want zij zijn zelf het beste in staat hun argumenten op tafel te leggen en zij weten wat het beste resultaat is. Van Schaick, die ook wel eens als rechter-plaatsvervanger optreedt, wordt soms wat angstig als hij in de raadkamer zit en rechters dan menen te weten wat zich precies allemaal heeft afgespeeld tussen partijen en wat er precies achter de rechtsstrijd schuilgaat. Daarom pleit hij van harte tegen meer vrijheid van rechters. Hij is voor een mondelinge behandeling, maar wel binnen de grenzen van het debat zoals die door partijen zijn getrokken.

Makkink is het deels met Van Schaick eens. Het in raadkamer filosoferen over wat partijen al dan niet hebben bedoeld, is volgens hem te laat, maar dient te gebeuren met partijen op de mondelinge behandeling, zodat een rechter hier ook nog wat mee kan doen in raadkamer. Een bezwaar dat hij deelt tegen de te activistische rechter die zelf rechtsgronden gaat aanvullen, is dat wanneer een rechter zelf iets aandraagt, hij als het ware overtuigd is van dat argument en ook de neiging heeft om te denken dat het een goed argument is. Een rechter moet volgens hem terughoudend zijn in het aanvullen van de rechtsgronden en nooit denken dat hij het beter weet dan partijen.

Makkink heeft partijautonomie altijd een lastig begrip gevonden. Partijen kunnen gezamenlijk bepalen, en voor een deel ook ieder voor zich, wat de omvang van de rechtsstrijd is. Volgens hem komt het echter bijna nooit voor dat partijen het gezamenlijk eens zijn over de omvang van de rechtsstrijd. Wanneer op de partijautonomie een inbreuk wordt gemaakt doordat de rechter iets aan de rechtsstrijd toevoegt, doet de rechter naar zijn idee niet iets tegen de gezamenlijke wil van partijen, omdat die wil vaak niet gezamenlijk is. Is er wel sprake van een gezamenlijke wil, dan is het volgens hem ook niet toegestaan dat de rechter iets toevoegt aan de rechtsstrijd.

\section{Inleiding mr. dr. R.J. Koopman}

Stellingen:

1. Het beginsel van hoor en wederhoor dwingt op zichzelf bezien niet tot invoering of handhaving van het grievenstelsel.

2. Het grievenstelsel wordt pas ingewikkeld in samenhang met andere procedureregels, zoals die van de 'bindende eindbeslissing'.

\section{Inleiding}

Koopman beziet het grievenstelsel vanuit het perspectief van de fiscalist. Hij schetst de geschiedenis van het hoger beroep in belastingzaken. In het belastingrecht bestaat pas sinds 2005 de mogelijkheid van hoger beroep. Voor 2005 bestond er een rechtsgang in twee fases. Eerst moest rechtstreeks beroep worden ingesteld bij een gerechtshof. Vervolgens kon tegen een uitspraak van het hof cassatie worden ingesteld. Sinds 2005 worden belastingzaken in eerste instantie behandeld door de rechtbanken, in hoger beroep door de gerechtshoven en in cassatie door de Hoge Raad. Het gevolg van deze wijziging was dat de bestuurssectoren van de rechtbanken zich moesten 
voorbereiden op belastingzaken. Hierdoor werden de cultuurverschillen tussen het belastingrecht en het overige bestuursrecht duidelijk. Dit leidde in eerste instantie tot strijd, maar is uiteindelijk effectief gebleken. Hij geeft als voorbeelden de finale geschilbeslechting, die eerder enkel in het belastingrecht gold, maar nu ook buiten het belastingrecht de norm is voor de bestuursrechter (art. 8:41a Awb), en de fuikenleer, die is teruggebracht tot de zogenaamde onderdelenfuik. De fuikenleer hield in dat nieuw bewijs of nieuwe gronden waarmee het bestuursorgaan bij zijn besluitvorming geen rekening had kunnen houden, in beginsel niet meer met succes voor de rechter konden worden aangevoerd. Met name de bewijsfuik kon vergaande consequenties hebben.

Koopman bespreekt de Brummenleer. ${ }^{10}$ Hiermee hebben volgens hem fiscalisten weinig te maken, maar deze geldt wel in het overige bestuursrecht. Deze leer heeft volgens Koopman raakvlakken met het grievenstelsel en de leer van de bindende eindbeslissing. De Brummenleer ziet op het geval waarin de rechtbank een zaak voor de tweede keer te behandelen krijgt, nadat zij de eerste keer het bestuursorgaan heeft opgedragen opnieuw op het bezwaar te beslissen. Als er tegen de eerste uitspraak van de rechtbank geen hoger beroep is ingesteld, kunnen partijen als zij voor de tweede keer voor de rechtbank staan, geen kwesties naar voren brengen waarover de rechtbank de eerste keer al heeft beslist. In het verlengde van de Brummenlijn ligt de afgeleide Brummenlijn. ${ }^{11}$ Deze houdt in dat degene die niet zelf hoger beroep heeft ingesteld, zich bij zijn verweer in appel niet kan beroepen op gronden die hij bij de rechtbank naar voren heeft gebracht, maar door de rechtbank zijn verworpen. Deze leer doet hem denken aan de leer van de bindende eindbeslissing in het burgerlijk recht. De Brummenleer is, naar zijn idee, in zijn uitwerking ingewikkeld en leidt tot een groot aantal vervolgvragen. Hij geeft als voorbeelden hiervan dat de Brummenlijn niet geldt als er een nauwe verwevenheid bestaat tussen de reeds besliste kwesties en de nog te beoordelen vragen, en dat de lijn niet wordt doorgetrokken naar gevallen waarin de betrokkene door bijzondere omstandigheden niet verweten kan worden dat hij geen appel instelde tegen de eerste beslissing. Verder rijzen volgens hem vragen over wat er moet gebeuren als de feitelijke omstandigheden of de toe te passen rechtsregel intussen zijn gewijzigd.

Het belastingrecht kan zich, volgens Koopman, op een betrekkelijk eenvoudige wijze onttrekken aan de Brummenlijn, omdat het geval waarvoor de lijn is ontwikkeld, zich in het belastingrecht zeer weinig voordoet. Wat betreft de afgeleide Brummenlijn heeft de Hoge Raad beslist dat deze niet geldt voor de belastingrechter. ${ }^{12}$ Koopman geeft aan dat in het verlengde hiervan geldt dat in het belastingrecht de partij die beroep of hoger beroep heeft ingesteld, in de loop van het geding haar gronden van beroep of hoger beroep kan aanvullen. Dit betekent dat partijen halverwege een procedure over

10. Zie ABRvS 6 augustus 2003, AB 2003/655.

11. Zie ABRvS 14 februari 2007, AB 2007/126

12. Zie HR 4 december 2009, BNB 2010/65; HR 16 april 2010, BNB 2010/228. een aanslag inkomstenbelasting hun bakens nog kunnen verzetten. Dit is slechts anders wanneer een partij de betreffende grond ondubbelzinnig heeft prijsgegeven of de goede procesorde in het gedrang komt. Hij geeft aan dat hierbij bedacht moet worden dat in het belastingrecht echter niet reformatio in peius geldt. De inspecteur kan met een nieuwe onderbouwing van de aanslag niet bewerkstelligen dat de rechter de aanslag zal vaststellen op een hoger bedrag aan te betalen belasting dan de inspecteur zelf heeft gedaan. Ook kan in hoger beroep een verwerende partij niet een beter resultaat bereiken dan de rechtbank haar heeft gegeven.

Op de door Koopman zelf opgeworpen vraag of in het belastingrecht geen grievenstelsel bestaat, geeft hij een genuanceerd antwoord. Degene die hoger beroep instelt, moet de gronden van het hoger beroep opnemen op straffe van een niet-ontvankelijkheidsverklaring. Wanneer 'gronden' door 'grieven' wordt vervangen, is het volgens hem duidelijk dat men in het belastingrecht ook een grievenstelsel kent. Het fiscale 'grondenstelsel' is naar zijn idee minder streng dan het civiele 'grievenstelsel'. In het belastingrecht geldt immers dat wanneer de indiener van het beroep of hoger beroep tijdig een grond heeft anngevoerd, hij door de ontvankelijkheidssluis is en daarna naar believen gronden kan aanvullen, mits de goede procesorde hierdoor niet wordt geschonden en de desbetreffende stelling niet eerder ondubbelzinnig is prijsgegeven.

Koopman durft niet te zeggen of de naar verhouding eenvoudige en ruimhartige fiscale doctrine zich ook leent voor toepassing in het burgerlijk procesrecht. Hij wijst wel op enkele verschillen tussen het burgerlijk proces en het fiscale proces. Het eerste verschil dat hij aanstipt, is dat de verhouding tussen de belastingheffende overheid en de burger bijzonder is. De Belastingdienst beschikt over vergaande bevoegdheden, zoals het zonder tussenkomst van de rechter executoriaal beslag leggen, en is 'superpreferent' schuldeiser. Een tweede verschil waar hij op wijst, is dat er in belastingzaken geen verplichte procesvertegenwoordiging bestaat. Dit geldt ook voor cassatie. Een derde verschil is dat het belastingrecht geen appellabele tussenbeslissing kent, waardoor ook nauwelijks wordt terugverwezen naar een bestuursorgaan. Waar dit wel gebeurt, ligt een streng grievenstelsel of een bestuursrechtelijke fuik volgens hem voor de hand om onnodig werk te voorkomen.

Koopman sluit af met de opmerking dat het grievenstelsel niet als een geïsoleerd verschijnsel kan worden bestudeerd en gewaardeerd.

\section{Discussie}

Smits (medewerker Wetenschappelijk Bureau van de Hoge Raad, fiscale sectie) merkt op bekend te zijn met het criterium van het ondubbelzinnig intrekken van een stelling en met het criterium van de goede procesorde. Hij memoreert dat in het belastingrecht geen verplichte procesvertegenwoordiging bestaat en vindt dit een goede zaak. Hij vraagt zich af in hoeverre de betrokkenheid van een professioneel gemachtigde belastingadviseur van invloed is op het criterium van het 
ondubbelzinnig intrekken van een stelling en het criterium van de goede procesorde.

Koopman antwoordt dat wat betreft het ondubbelzinnig intrekken er weinig mogelijkheden zijn voor nuancering. Volgens hem geldt voor iemand die zonder verplichte procesvertegenwoordiging ondubbelzinnig heeft ingetrokken, hetzelfde als voor iemand die dat bij monde van een advocaat doet. Naar zijn idee zijn uitingen van iemand die zonder procesvertegenwoordiging procedeert voor een jurist vaak minder ondubbelzinnig, waardoor hier misschien meer ruimte ligt. Wat betreft de goede procesorde denkt hij dat ook daar de norm hetzelfde blijft. Wel kan volgens hem de invulling verschillen al naar gelang de rechter te maken heeft met iemand die de procesregels goed kent en een 'one shooter'. Ter verduidelijking geeft Koopman het volgende voorbeeld. Wanneer een partij nalaat bij de rechtbank haar kaarten op tafel te leggen, terwijl zij goed weet dat zij dit behoort te doen, kan deze partij eerder een verwijt worden gemaakt als zij pas bij het hof met bepaald bewijs komt dan de 'one shooter' die denkt op de zitting nog met geweldige vondsten te mogen komen. Koopman hoopt dat de Hoge Raad op dit punt abstracte regels kan geven die de rechtbanken en de hoven de mogelijkheid bieden daar met wijsheid mee om te gaan, rekening houdend met de concrete situatie en dus ook met de mate van deskundigheid van de partijen.

De voorzitter stelt aan de vergadering de vraag of het civiele procesrecht wat kan leren van het belastingrecht in de zin dat op het terrein van het civiele appel nog ruimer nieuwe argumenten/nieuwe bezwaren naar voren gebracht zouden moeten kunnen worden, of dat de geschetste verschillen tussen het belastingrecht en het civiele recht hieraan in de weg staan.

Wiersma stelt in reactie op de vraag van de voorzitter aan Koopman de vraag of er in het belastingrecht ook sprake is van tijdsdruk. Het civiele procesrecht wordt volgens hem erg gekenmerkt door het feit dat de appelprocedure met de grootste voortvarendheid moet worden betracht.

Koopman antwoordt dat die tijdsdruk ook speelt in het belastingrecht. Er wordt benadrukt dat snelheid een aspect is van kwaliteit. Dit is volgens hem in het belastingrecht een breder probleem. In het belastingrecht wordt maar weinig geprocedeerd omdat men het zich in het bedrijfsleven niet kan veroorloven om een grote onzekere belastingclaim lang in de jaarstukken te laten staan. Hij geeft aan dat er op dit moment wordt gesproken over mogelijkheden om in een heel vroeg stadium bepaalde geschilpunten definitief te kunnen beslechten door middel van een bepaalde procedure. Dat is op dit moment nog niet mogelijk. De procedures gaan altijd over aanslagen die na afloop van het jaar zijn vastgesteld, waarover dan nog een bezwaarfase komt, rechtbank, hof en Hoge Raad. Dit duurt jaren en daarom wordt er volgens hem op het gebied van vennootschapsbelasting en winstbelasting door bedrijven weinig geprocedeerd.

Schurink (advocaat te Huizen) reageert op de vraag van de voorzitter en denkt dat een groot verschil tussen het civiele procesrecht en het belastingrecht is dat in het fiscale recht de overheid een van de partijen is die de andere partij iets heeft opgelegd. Dit is volgens hem een zo groot verschil dat de regels van fiscaal recht niet naar het civiele recht kunnen worden vertaald.

Koopman antwoordt dat hij zich dit kan voorstellen. Daarnaast heeft hij het idee dat er een groot verschil is doordat in het belastingrecht niet wordt gewerkt met tussenbeslissingen. Daar wordt eerst een beroepschrift ingediend, dan komt er een verweerschrift, eventueel re- en dupliek, en daarna een mondelinge behandeling. Er wordt door de rechter niets gezegd over de bewijslast en of hier al dan niet aan is voldaan. De rechter beslist vervolgens bij eindvonnis of het bewijs al dan niet voldoende was. Wanneer een partij het daar niet mee eens is, kan deze in appel bij het hof. $\mathrm{Er}$ is dus geen 'tweede ronde' bij de rechtbank en dit zorgt volgens hem voor een soort versnelling ten opzichte van het civiele recht, omdat daar wel met tussenbeslissingen wordt gewerkt, waartegen onder omstandigheden ook nog appel openstaat.

Kastein (advocaat te Zevenaar) geeft een aanvulling op het punt betreffende de tussenvonnissen. Volgens hem is de noodzaak van tussenvonnissen minder aanwezig als gevolg van het vooronderzoek dat plaatsvindt in het bestuursrecht. Tijdens dit vooronderzoek ontvangen partijen brieven voor de zitting, waarin wordt verzocht bepaalde stukken aan te leveren en waarin wordt aangegeven wat tijdens de zitting aan de orde zal komen. Verder stelt hij naar aanleiding van de inleiding van Makkink een vraag aan Koopman. Door Makkink is besproken dat de taak van de burgerlijke rechter toeneemt doordat de rechter ambtshalve moet toetsen aan regels van consumentenbescherming. De bestuursrechter is het volgens Kastein al gewend om te toetsen aan begrippen van openbare orde. Hij vraagt zich af of de belastingrechter er ook moeite mee heeft dat hij naast een ambtshalve taak ook nog gewoon werk heeft.

Koopman antwoordt dat de ambtshalve taak lastig is. Deze moet volgens hem op basis van het dossier worden vervuld en hiervoor dienen niet allerlei stukken te worden opgevraagd. Volgens hem is het daarnaast zo dat de mogelijkheid van ambtshalve ingrijpen veel rechters de gelegenheid biedt hun stokpaardjes te berijden.

\section{Inleiding prof. mr. A.I.M. van Mierlo}

Stellingen:

1. De behandeling in hoger beroep dient niet afhankelijk te zijn van de wijze van financiering van de gerechtshoven.

2. In zowel vorderingsprocedures als verzoekprocedures dient het hogerberoepschrift de gronden van het hoger beroep te bevatten.

3. Grieven moet (en in één keer).

4. De door sommigen bepleite afschaffing van de positieve zijde van de devolutieve werking verdient geen navolging.

5. Het bepaalde in art. 357 en $361 \mathrm{a} \mathrm{Rv}$ (nieuw) is - reeds op voorhand - een dode letter. 


\section{Inleiding}

Van Mierlo begint zijn inleiding met de opmerking dat het procesrecht sinds het begin van deze eeuw in beweging is. In dit verband wijst hij allereerst op de wetgevingsoperatie van 2002, maar ook op ontwikkelingen die in 2015 zullen gaan plaatsvinden, zoals de herschikte EEX-verordening (Brussel I), die van toepassing is met ingang van 10 januari 2015, de nieuwe Arbitragewet, die per 1 januari 2015 in werking treedt, en het wetsvoorstel tot wijziging van het Wetboek van Burgerlijke Rechtsvordering en de Algemene wet bestuursrecht in verband met vereenvoudiging en digitalisering van het procesrecht, dat vanaf 1 juli 2015 operationeel moet zijn.

Het conceptvoorstel tot wijziging van het Wetboek van Burgerlijke Rechtsvordering in verband met vereenvoudiging en digitalisering van het procesrecht in hoger beroep en cassatie borduurt voort op het wetsvoorstel tot wijziging van het Wetboek van Burgerlijke Rechtsvordering en de Algemene wet bestuursrecht in verband met vereenvoudiging en digitalisering van het procesrecht. De voorstellen voor de procedure in hoger beroep zijn volgens Van Mierlo niet spectaculair. Aan de klassieke contouren wordt volgens hem niet gesleuteld. Het grievenstelsel, de daarmee samenhangende devolutieve werking (positief en negatief) en de twee-conclusie-regel blijven behouden. Dit vindt hij niet bezwaarlijk, zoals ook al blijkt uit zijn derde en vierde stelling. Hij wil in zijn inleiding enige opmerkingen maken die mogelijk aanleiding geven om ook het hoger beroep in beweging te krijgen.

Allereerst gaat Van Mierlo in op het hogerberoepschrift. Hij wijst erop dat ingevolge het conceptwetsvoorstel tot vereenvoudiging en digitalisering van het hoger beroep en cassatie wat betreft het stadium waarin grieven moeten worden aangevoerd er geen verandering optreedt. In hoger beroep bij de verzoekprocedure blijft de eis dat het hogerberoepschrift de gronden moet bevatten, bestaan doordat art. $359 \mathrm{Rv}$ (nieuw) evenals het huidige art. $358 \mathrm{Rv}$ verwijst naar de bepaling omtrent de inhoud van het verzoekschrift in eerste aanleg (art. $278 \mathrm{Rv}$ ). Voor het hoger beroep in vorderingszaken blijft indiening van een hogerberoepschrift zonder grieven (gronden) toegestaan. Weliswaar zou de eiser in beginsel zijn gronden voor het hoger beroep moeten opnemen, maar in art. 343 lid $2 \mathrm{Rv}$ (nieuw) wordt rekening gehouden met de huidige praktijk. In deze bepaling is bepaald dat wanneer het hogerberoepschrift de gronden niet bevat, de rechter bepaalt dat de gronden binnen een termijn van maximaal tien weken moeten worden aangevuld. Het is volgens Van Mierlo een gemiste kans dat appellant niet wordt verplicht de grieven in het hogerberoepschrift op te nemen. De in eerste aanleg zo wenselijk geachte 'voortgang in de procedure' en de wens het processuele debat zo snel mogelijk bij de rechter op tafel te leggen, gelden volgens hem ook in hoger beroep. Dit had op een eenvoudige wijze kunnen worden bereikt door zowel voor de vorderingsprocedure als voor de verzoekprocedure verplicht te stellen dat in het hogerberoepschrift de grieven worden opgenomen. Dit brengt hem dan ook tot zijn tweede stelling.

De reden waarom de wetgever er niet voor heeft gekozen om ook voor de vorderingsprocedure verplicht te stellen dat in het hogerberoepschrift de grieven worden opgenomen, is dat de praktijk van de comparitie na aanbrengen hierdoor zou worden gehinderd. Van Mierlo begrijpt deze redenering niet. Volgens hem komt de gedachtewisseling veel beter op gang als de verschillen van mening over de inhoud van het vonnis waarvan beroep en het verweer bij de raadsheer uitgeschreven op tafel liggen. De vraag dringt zich bij hem op of achter de door de wetgever gegeven reden niet iets heel anders schuilgaat. Hij sluit niet uit dat het te maken heeft met de financiering. Het bereiken van een schikking heeft immers tot gevolg dat de 'belastingtijd' van het gerechtelijk apparaat en daarmee de kosten afnemen. Dit verklaart ook zijn eerste stelling.

De derde stelling van Van Mierlo luidt: 'Grieven moet (en in één keer).' Hij is voor handhaving van het grievenstelsel. De reden die hij hiervoor geeft, is dat grieven de omvang van de rechtsstrijd in hoger beroep vastleggen, wat zorgt voor een ordening van het processuele debat, hetgeen de proceseconomie ten goede komt. Het grievenstelsel en de daarbij behorende 'twee-conclusie-regel' blijven ook in het wetsvoorstel tot wijziging van het procesrecht in hoger beroep en cassatie gehandhaafd. Volledigheidshalve wijst hij erop dat binnen het Nederlandse Koninkrijk het Caribische deel geen grievenstelsel kent.

Betreffende zijn vierde stelling merkt Van Mierlo op dat hij zich afvraagt of afschaffing van de positieve zijde van de devolutieve werking gaat 'vliegen'. Volgens hem zijn hiervoor flankerende eisen noodzakelijk en hij verwijst hiervoor naar de suggestie die Wesseling-van Gent deed tijdens de vergadering van de NVvP in 2010. Wesseling-van Gent opperde dat de geïntimeerde aangeeft waar hij het al dan niet mee eens is en welke onderdelen die in eerste aanleg aan de orde zijn geweest, kunnen blijven rusten. ${ }^{13}$

De laatste stelling van Van Mierlo ziet op art. 357 en 362a $\mathrm{Rv}$ (nieuw). In deze bepalingen is een termijn voor het doen van een uitspraak in hoger beroep opgenomen. Deze termijn bedraagt voor een uitspraak in vorderingszaken tien weken, in verzoekzaken zes weken en in kort geding zes weken. De wet kent in alle gevallen een verlengingsmogelijkheid. $\mathrm{Hij}$ is op basis van recente ervaringen met verschillende gerechten droevig gestemd op het punt van de termijn van het doen van een uitspraak en denkt dat de verlengingsmogelijkheid noodzakelijk is. Hierdoor zijn volgens hem art. 357 en 361a (nieuw) Rv op voorhand een dode letter.

\section{Discussie}

Snijders (advocaat te Utrecht) stelt aan Makkink de vraag of hij niet te somber is over het arrest Fafianie/KSN. Hij vraagt zich af of, zoals Wiersma al aangaf, in dit arrest niet een 'hard and fast rule' is geformuleerd. Volgens hem heeft de Hoge Raad in dit arrest geoordeeld dat wanneer een partij niet in appel gaat voor een gedeelte van het vonnis, dat gedeelte tussen partijen in kracht van gewijsde gaat en dit alles beperkend is tussen partijen. Naar zijn idee had dit ook in het arrest Van Gaalen/LTO het geval moeten zijn.

13. Zie G.C.C. Lewin e.a., Hoger beroep (procesrechtelijke reeks NVvP), Den Haag: Sdu Uitgevers 2011, p. 59. 
Makkink antwoordt dat hij het daar wel mee eens kan zijn, maar vindt dat het vanuit de positie van KSN mogelijk moet zijn dat er geen incidenteel appel wordt ingesteld maar het wel mogelijk moet zijn dat KSN kan voorkomen dat er meer wordt toegewezen dan in eerste aanleg is toegewezen, omdat KSN kan leven met het vonnis in eerste aanleg, en daar ook argumenten voor heeft. Hiervan kan volgens Makkink worden gezegd dat dit in strijd is met het gezag van gewijsde, maar dit is volgens hem techniek, en hij ervaart dit als een nadeel.

De voorzitter legt aan de vergadering voor de door Van Mierlo in zijn inleiding naar voren gebrachte stelling dat het grievenstelsel moet worden behouden, maar dat de grieven in het hogerberoepschrift zelf naar voren moeten worden gebracht en niet later in de procedure. Van Mierlo heeft gesteld dat het argument van de wetgever om dit niet te doen, is dat de praktijk van de comparitie na aanbrengen hierdoor zou worden gehinderd. Dit argument snijdt volgens hem geen hout. De voorzitter geeft aan dat de wetgever ervoor heeft gekozen niet de eis te stellen dat de grieven in het hogerberoepschrift worden opgenomen, omdat dit afbreuk zou kunnen doen aan de kwaliteit van de grieven doordat in de praktijk toch vaak redelijk tegen het einde van de appeltermijn een beroepschrift wordt uitgebracht. De voorzitter vraag een reactie van de vergadering op dit punt.

Duk (hoogleraar te Rotterdam en advocaat te Den Haag) geeft aan dat hij een tegenstander is van de door Van Mierlo geopperde regel van het onmiddellijk aanvoeren van de grieven. Volgens hem dringt zich hier wel de vergelijking op met cassatie. Hier moeten de middelen ook binnen drie maanden worden geformuleerd, terwijl advocaten ook daar pas het dossier na zes, acht of tien weken ontvangen. Hij komt tot de conclusie dat het wel mogelijk is om in het hogerberoepschrift de gronden op te nemen. Volgens hem zijn er echter argumenten voor en tegen het opnemen van de grieven in het hogerberoepschrift. Een argument tegen is dat partijen op kosten worden gejaagd wanneer tijdens het overleg appel wordt ingesteld en dan direct een memorie moet worden opgesteld. Hij heeft een aantal zaken gehad waarin appel werd ingesteld - zoals dat volgens hem ook wel eens bij cassatie gebeurt - hangende het overleg tussen partijen. Er is volgens hem een eenvoudige oplossing. De partij die appelleert, dient aan de rechter te laten weten wat ze wil en vervolgens dient de rechter dan een ordebeslissing te nemen wat betreft het indienen van de grieven, waarbij rekening kan worden gehouden met mogelijk overleg tussen partijen. Meer principieel geeft Duk aan dat hij vindt dat er veel meer overleg tussen de rechter en partijen behoort te zijn op dit soort fronten.

Van Mierlo vindt maatwerk prachtig, maar vindt dat in het merendeel van de gevallen de rechter hiermee niet moet worden lastiggevallen. Hij maakt de vergelijking met escalatieregelingen in contracten, waarin is bepaald hoe moet worden onderhandeld en binnen welke termijn. In appel zou hetzelfde moeten gelden. Partijen weten wanneer een memorie van grieven moet worden ingediend en men kan ook een termijn stel- len voor het onderhandelen. Hij denkt dat, hoewel het argument van Duk valide is, het aantal gevallen waarin het slecht afloopt, meevalt. Daarom kiest hij toch voor de grote meerderheid en voor het opnemen van de grieven in het hogerberoepschrift.

Bruning (advocaat te Den Haag) wil Makkink complimenteren met de aangedragen oplossing. Hij denkt dat in het debat over de vraag of grieven voor een comparitie na aanbrengen zouden moeten worden aangebracht of daarna, zoals nu het geval is, de waarborgen van art. 6 EVRM een rol spelen, in het bijzonder 'fair trial' en 'equality of arms'. Volgens hem hebben advocaten bij de comparitie na aanbrengen vaak het gevoel dat de raadsheer-commissaris voor zijn beurt spreekt en misschien wel de andere partij op een idee brengt welke grieven moeten worden aangevoerd. Hij is het met Van Mierlo eens dat de comparitie na aanbrengen te veel voorin in de procedure zit om uiteindelijk de gelijkwaardige bejegening van partijen in het kader van het partijdebat te kunnen waarborgen.

Bruning geeft aan dat hij, evenals Van Mierlo, een voorstander is van het opnemen van de grieven in het inleidende stuk. Een voordeel daarvan is volgens hem dat de advocaat de zaak in eerste aanleg nog goed in het hoofd heeft en daardoor heel gericht grieven kan formuleren tegen de uitspraak in eerste aanleg. Het is echter de vraag of de grieven dan ook direct dienen te worden toegelicht, omdat het mogelijk is dat op dat moment nog niet al het bewijsmateriaal voorhanden is om een goede toelichting te geven. Het opnemen van de grieven in het inleidende stuk leidt volgens hem dan tot een systeem dat een vrij en open debat zal moeten openstellen aan beide partijen, niet met een positieve zijde van de devolutieve werking van het appel die de geïntimeerde in bescherming neemt, maar met gelijkwaardigheid in de bejegening van procespartijen. Wanneer dan de vraag komt of later grieven nog zijn toegestaan, dient dit naar zijn idee te worden beantwoord aan de hand van de goede procesorde. Volgens hem blijkt uit het feit dat het in cassatie en in appel in de verzoekschriftprocedure ook mogelijk is, dat in het procesinleidende stuk de grieven kunnen worden opgenomen.

Bruning vraagt aan Makkink wat hij verstaat onder de grieven die hij in het inleidende stuk voor ogen heeft. Daarnaast merkt hij ten aanzien van het voorstel van Makkink op dat als de appelrechter op de mondelinge behandeling de verweren van partijen in eerste aanleg onder de aandacht brengt en vraagt of partijen die ook nog besproken willen hebben, hierin het risico schuilgaat dat de appelrechter een beslissing geeft en een van de partijen toch wel graag had gehad dat een verweer in eerste aanleg daarbij was betrokken, maar de appelrechter dit op de mondelinge behandeling onbesproken heeft gelaten en partijen het hierover niet hebben gehad.

Makkink is het eens met Van Mierlo dat het een gemiste kans is dat in het conceptwetsvoorstel tot vereenvoudiging en digitalisering van het hoger beroep en cassatie niet de regel is ingevoerd dat ook voor de dagvaardingsprocedure in het inleidende stuk de grieven moeten worden opgenomen. Met grieven bedoelt hij de grieven in de 'klassieke' zin, dus de bezwaren 
tegen het vonnis in eerste aanleg. Zijn voorstel houdt dus niet in dat er een onbeperkte mogelijkheid bestaat om bij de mondelinge behandeling na antwoord nog met allerlei nieuwe grieven te komen. Hij ziet de mondelinge behandeling als een moment om gezamenlijk en met een zekere redresseringsmogelijkheid de omvang van het appel af te hechten, zodat gezamenlijk wordt vastgesteld waar partijen en de appelrechter het over gaan hebben. Wat betreft de vraag hoe ruim die redresseringsmogelijkheid is, dient volgens Makkink voorop te blijven staan dat de bezwaren die een partij heeft tegen een vonnis in het inleidende appelprocesstuk moeten staan, en in die zin zijn dat dus grieven in klassieke zin. Hij is geen voorstander van de comparitie na aanbrengen. Naast de bezwaren die al naar voren zijn gebracht, vindt hij de tamelijk onmogelijke positie waarin de partij verkeert die in eerste aanleg gelijk heeft gekregen een bezwaar. Deze partij heeft het volgens hem moeilijk om haar positie te bepalen. De in eerste aanleg in het ongelijk gestelde partij krijgt, zonder het maken van relevante kosten, een soort van herkansing. Dit is volgens hem niet fair.

Van Mierlo hoort graag vanuit de zaal de ervaringen met de comparitie na aanbrengen.

Van Dijk (advocaat te Arnhem) heeft veel ervaring met de comparitie na aanbrengen en is hier ook enthousiast over, ondanks dat deze niet altijd uitmondt in een schikking. Ook dan is het verhelderend omdat er vrij open wordt gecommuniceerd over de grieven. De gehoorde bezwaren deelt hij niet. Het is volgens hem niet zo dat de geïntimeerde achterover kan leunen. Er ligt immers een hoger beroep waarover de appelrechter moet oordelen. Wanneer de comparitie na aanbrengen niet uitmondt in een schikking heeft hij nooit ervaren dat deze problemen heeft opgeleverd in het vervolg van de procedure. Hij vindt de comparitie na aanbrengen een prijzenswaardig initiatief.

Valk is blij met de positieve ervaring van Van Dijk, maar kan zich best voorstellen dat er ook wel eens een negatieve ervaring is met de comparitie na aanbrengen. Het verloop van de comparitie na aanbrengen hangt sterk af van de taakopvatting en het vakmanschap van de betrokken rechter, waardoor een zitting minder voorspelbaar is dan alleen maar schriftelijk procederen. Valk staat kort stil bij de oorspronkelijke doelstelling van de comparitie na aanbrengen. De bedoeling van de comparitie na aanbrengen was volgens hem het bieden van service in gevallen waar sprake is van een gering financieel belang of een verhouding van mensen die met elkaar verder moeten. $\mathrm{Om}$ in die situatie even stil te staan bij het feit dat hoger beroep is ingesteld en er daarmee opnieuw onzekerheid is over de uitkomst van de procedure, en zo te kijken of er weer kansen zijn. Deze kansen kunnen volgens Valk in verschillende punten zitten en hoeven niet in een schikking te zitten. Hij geeft als voorbeeld dat beide partijen het eens zijn dat het cruciaal is dat bepaalde getuigen worden gehoord die in eerste aanleg niet zijn gehoord. Hierover kunnen partijen dan bij de comparitie na aanbrengen afspraken maken. Hij ziet wel voordelen van het opnemen van de grieven in het procesinleidende stuk. Het huidige systeem brengt mee dat een partij in appel gaat met het idee dat zij nu nog niets inhoudelijks hoeft op te schrijven en er een kans bestaat dat er een comparitie na aanbrengen komt.

Kalff (advocaat te Amsterdam) wil een tegengeluid laten horen tegen de comparitie na aanbrengen. Hij heeft hier één keer mee te maken gehad en vond dit een oppervlakkige bijeenkomst, omdat de rechtsstrijd en grieven niet bekend waren. $\mathrm{Hij}$ is eveneens een voorstander van het opnemen van grieven in het inleidende stuk. Daarnaast is hij ook een voorstander van het voorstel van Makkink om in de appelprocedure altijd een mondelinge behandeling te laten plaatsvinden. Volgens hem heeft de mondelinge behandeling, zoals ook blijkt uit de comparitie na antwoord in eerste aanleg, een bijzondere dynamiek die de rechtsstrijd kanaliseert. De mondelinge behandeling voorkomt verrassingen in het arrest en maakt helder waar partijen het over hebben. Hij zou de mondelinge behandeling niet na aanbrengen doen, maar na de schriftelijke stukkenwisseling. Dan bestaat volgens hem de beste uitgangspositie om te kanaliseren waar de zaak in appel over gaat en wordt er een arrest gewezen dat zo min mogelijk verrassingen bevat.

Tanja-van den Broek (raadsheer bij de Hoge Raad) wil de vergadering informeren over het reglement Versneld Innovatief Appel (VIA), dat een paar jaar geleden is opgesteld door de Intellectuele Eigendom-sectie (IE-sectie) van het Haagse hof. Dit reglement 'slaapt' op dit moment nog. Volgens haar is een aantal voorstellen dat tijdens de vergadering voorbij is gekomen, in dit reglement opgenomen: (1) grieven moeten in het eerste stuk worden opgenomen; (2) na het antwoord vindt er altijd een mondelinge behandeling plaats; en (3) na het aanbrengen van een zaak wordt er direct een regieraadsheer benoemd die met partijen de proceswensen doorneemt en een tijdpad uitzet, waarbij de uitspraak in beginsel altijd binnen acht maanden plaatsvindt. Dit reglement slaapt omdat daarin ook is opgenomen dat de devolutieve werking wordt uitgeschakeld. Reden voor de uitschakeling ervan is dat wanneer binnen acht maanden arrest moet worden gewezen, de appelrechter niet genoodzaakt moet zijn eindeloos uit het dossier uit de eerste aanleg te moeten putten. De stellingen die partijen wensen te handhaven, dienen binnen vijf pagina's te worden neergelegd. Om de devolutieve werking overboord te zetten en de processtukken in omvang te beperken is toestemming van procespartijen vereist, en die wordt in IE-zaken niet verleend.

Bruning merkt op dat de mondelinge behandeling, de regiezitting, zoals deze tijdens de vergadering is besproken, veel wordt toegepast in verwijzingsprocedures. Wanneer de Hoge Raad de zaak casseert en verwijst naar een ander hof, dan gelast dat andere hof een comparitie om te kijken waar partijen staan, wat er nog over is van de rechtsstrijd en of er nog een bewijsincident dient plaats te vinden. Dit werkt volgens hem erg goed. 
De voorzitter geeft ter afronding een korte conclusie, dankt de sprekers en sluit de vergadering. 